\title{
Inhibition of histone acetyltransferase (HAT) activity by HBZ extends beyond the p300/CBP HAT family
}

\author{
Diana G Wright ${ }^{*}$, Nicholas Polakowski, Isabelle Lemasson
}

From 16th International Conference on Human Retroviruses: HTLV and Related Viruses

Montreal, Canada. 26-30 June 2013

We previously reported that HTLV-1 basic leucine zipper factor (HBZ) interacts with the cellular coactivator p300 in cells derived from ATL patients. We further determined that HBZ directly binds to the histone acetyltransferase (HAT) domain of both p300 and its homologue CBP. HAT activity transfers an acetyl group to lysine residues on histone tails and transcription factors to generally upregulate transcription. We observed that the HBZ interaction with the HAT domain of p300/CBP inhibits acetylation of histones and of the tumor suppressor $\mathrm{p} 53$. In this study, we wanted to determine whether inhibition of HAT activity was limited to p300/CBP or extended to other HAT families. We focused on the GCN5/ p/CAF and MYST HAT families. We found that HBZ co-immunoprecipitates with both $\mathrm{p} / \mathrm{CAF}$ and HBO1. These data support a recent finding that HBZ interacts with $\mathrm{HBO} 1$ in a yeast two-hybrid assay. Through in vitro HAT assays using recombinant proteins we found that $\mathrm{HBZ}$ inhibits acetylation of histone $\mathrm{H} 3$ and histone $\mathrm{H} 4$ by $\mathrm{p} / \mathrm{CAF}$ and $\mathrm{HBO} 1$, respectively. Furthermore, HBZ reduces acetylation of p53 by p/CAF. Since both p300 and p/CAF acetylate p53 to increase its DNA-binding activity, we performed quantitative RTPCR to evaluate expression of the p53 target genes, GADD45A and NOXA. We observed reduced mRNA levels of these genes when cells expressed HBZ. Overall these results suggest that HBZ inhibits the HAT activity of coactivators from different HAT families to contribute to transcriptional deregulation.
Published: 7 January 2014

doi:10.1186/1742-4690-11-S1-P109

Cite this article as: Wright et al: Inhibition of histone acetyltransferase (HAT) activity by HBZ extends beyond the p300/CBP HAT family. Retrovirology 2014 11(Suppl 1):P109.

* Correspondence: Wrightdi09@students.ecu.edu Department of Microbiology and Immunology East Carolina University, Brody School of Medicine, Greenville, NC, USA

Submit your next manuscript to BioMed Central and take full advantage of:

- Convenient online submission

- Thorough peer review

- No space constraints or color figure charges

- Immediate publication on acceptance

- Inclusion in PubMed, CAS, Scopus and Google Scholar

- Research which is freely available for redistribution
C Biomed Central 